\begin{tabular}{|l|l|l|l|l|l|}
\hline J. Tek. Ling & Vol. 12 & No. 2 & Hal. 153 - 160 & Jakarta, Mei 2011 & ISSN 1441-318X \\
\hline
\end{tabular}

\title{
PENGARUH RADIASI SINAR GAMMA TERHADAP PERTUMBUHAN DAN PERUBAHAN FENOTIPE TUNAS IN VITRO LIDAH BUAYA (ALOE VERA)
}

\author{
M. Imelda, L. Sari, A. Wulansari and F. Erlyandari* \\ Pusat Penelitian Bioteknologi, LIPI \\ Jl.Raya Bogor Km 46, Cibinong 16911,Bogor
}

\begin{abstract}
Aloe vera (L.) Burm.f. of the Asphodelaceae, which probably originated in North Africa is a very short-stemmed succulent, perennial plant of $80-100 \mathrm{~cm}$ in height. Today, it is widely grown in the tropics worldwide. It has long been used as a traditional herbal medicine and as cosmetic materials since thousand of years BC in Egypt, China, Greece, etc. It can be used externally to treat various skin conditions and It was useful for curing diabetics, cancer, HIV, even for stress and drug addicts The biologically active components found in the juice of aloe leaves are anthraquinones, acemannan, and prostaglandins. Chunks of aloe pulp are popular as beverages in Asia. Aloe has long been propagated by splitting its off-shoots, and this may account for its narrow genetic variations. In this research, genetic variations of $A$. vera and $A$. vera var. Chinensis, were induced by gamma irradiation. In vitro shoots of Aloe were irradiated with gamma ray at the dosage of 10-60 gy, then propagated on Murashige and Skoog (MS) solid medium containing $1 \mathrm{mg} / \mathrm{l} B A P$. The results showed that shootlets of $A$. vera var. Chinensis were still alive up to 40 gy but the leaves became stiffer, while $A$. vera only tolerated irradiation up to 20gy. At 50-60 gy, all cultures died after 2 months. Visual observation on irradiated in vitro shoots showed that new variants appeared at the dosage of $20 \mathrm{gy}$, although in very low frequencies. Leaves became half green and half white in A. vera and white-green-white in A. vera var. Chinensis. Confirmation whether those variants were of genetic or morphological origin needs to be further investigated.

* Peneliti magang
\end{abstract}

Key Words Aloe vera, A.vera var. Chinensis, radiasi sinar gamma, perubahan morfologi

\section{PENDAHULUAN}

\subsection{Latar Belakang}

Lidah buaya (Aloe vera (L.) Burm.f.) dari suku Aloecaceae, telah digunakan sebagai obat sejak ribuan tahun sebelum Masehi. Penggunaan lidah buaya sebagai obat tradisional telah lama dilakukan di Mesir, China, Yunani, Spanyol, Saudi Arabia dan di berbagai negara lainnya. Lidah buaya segar mengandung air, mineral, protein, lemak, karbohidrat, enzim dan vitamin. Gel lidah buaya mengandung acemanan, glukomanan (polisakarida), bradikinase, anti-prostaglandin, anti-inflamatori dan anti bakteri. Pada saat ini sedang diteliti pengaruh antiviral dan imunomodulator lidah buaya untuk mengobati diabetes, herpes, kanker, dan HIV ${ }^{1}$. Penggunaan 
lidah buaya sebagai obat diabetes secara tradisional telah banyak diterapkan ${ }^{2,3)}$. Bahan aktif yang dikandungnya antara lain adalah aloin, barbaloin, isobarbaloin, aloenin, aloe-emodin, aloesin yang memiliki efek farmakologi sebagai anti radang, anti pencahar, anti diabetes dan lain-lain.

Di Indonesia, lidah buaya umumnya dibudidayakan sebagai tanaman pekarangan atau tanaman hias pot namun di Kalimantan Barat, A. vera var. Chinensis sudah dibudidayakan secara besar-besaran untuk dijadikan minuman segar, teh, manisan, dodol dan lain-lain. Prospek pengembangan tanaman lidah buaya sangat cerah mengingat tanaman ini telah dimanfaatkan sebgai bahan baku obat di 23 negara dan telah tercantum dalam Daftar Tanaman Obat Prioritas WHO. Permintaan bahan baku lidah buaya untuk industri obat dan kosmetika serta untuk industri makanan dan minuman dalam dan luar negri masih cukup tinggi dan belum terpenuhi ${ }^{4)}$.

Perbanyakan vegetatif yang dilakukan secara terus-menerus dalam jangka waktu lama pada lidah buaya, mengakibatkan variasi genetiknya menjadi sangat sempit. Pemuliaan lidah buaya hampir tidak pernah dilakukan, sedangkan silangan alami sulit terjadi karena adanya sterilitas bunga jantan. Oleh sebab itu, induksi mutasi merupakan cara alternatif yang memberi harapan bagi peningkatan mutu tanaman yang biasa diperbanyak secara vegetatif. Dengan cara tersebut, hanya sedikit sifat yang berubah sedangkan sebagian besar sifat lainnya tetap atau tidak berubah. Mutasi dapat dilakukan melalui perlakuan fisik atau kimia untuk perbaikan mutu genetik seperti meningkatkan produktivitas, ketahanan terhadap penyakit tertentu, umur panen yang lebih pendek, toleran terhadap $\mathrm{pH}$ tinggi ${ }^{5}$. Sinar gamma, sinar ultra violet ataupun sinar $\mathrm{X}$ merupakan mutagen fisik yang sering digunakan bagi peningkatan mutu tanaman ${ }^{6)}$.

. Induksi mutasi yang dilakukan dengan sinar gamma dan diperkuat dengan variasi somaklonal yang mungkin muncul dalam proses perbanyakan melalui kultur jaringan, diharapkan dapat meningkatkan efisiensi munculnya keragaman genetik yang sangat minimal pada lidah buaya. Meningkatnya keragaman genetik lidah buaya tersebut sangat mendukung usaha pemuliaan dan konservasinya.

\subsection{Tujuan}

Penelitian ini bertujuan untuk memperluas keragaman genetik lidah buaya melalui mutagenesis in vitro yaitu gabungan antara teknik mutasi dan teknik in vitro atau teknik kultur jaringan.
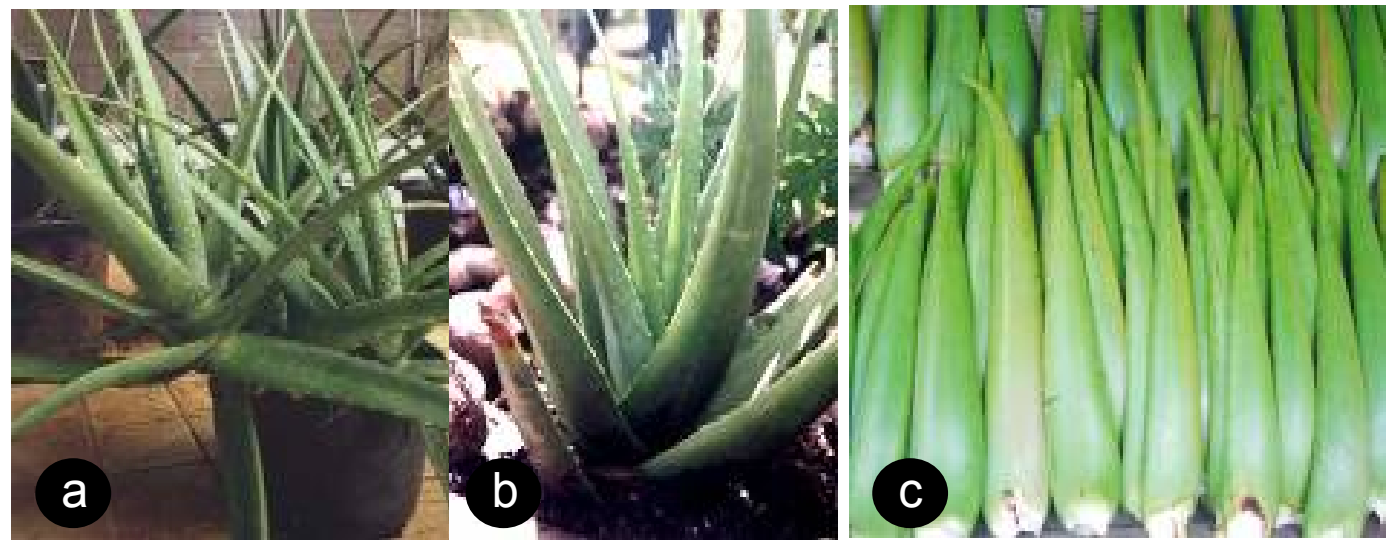

Gambar 1 : Tanaman lidah buaya, a. Aloe vera; b. .A. vera var Chinensis; c. Daun A.vera var Chinensis 


\section{BAHAN DAN METODE}

\subsection{Bahan Tanaman}

Aloe vera (Gambar 1 a) dan Aloe vera var. Chinensis (Gambar 1 b) yang berasal dari Rumah Kaca Puslit Bioteknologi, LIPI, Cibinong, merupakan dua kultivar lidah buaya yang akan diteliti pada tahun ini. Tanaman yang tingginya $\pm 5-7 \mathrm{~cm}$, diambil tunas pucuknya dan digunakan sebagai bahan eksplan.

\subsection{Media proliferasi}

Untuk proliferasi tunas in vitro digunakan media Murashige \& Skoog (MS) $)^{7}$ yang mengandung gula $30 \mathrm{~g} / \mathrm{l}$ serta agar Gelrite $2 \mathrm{~g} / \mathrm{l}$. Keasamannya diatur sampai mencapai $\mathrm{pH} \mathrm{5,8} \mathrm{lalu} \mathrm{diautoklaf} \mathrm{pada} \mathrm{suhu} 121^{\circ} \mathrm{C}$, tekanan $1 \mathrm{~atm}$ selama 15 menit. Setelah dingin dan disimpan 1-2 hari, media yang terkontaminasi dibuang sedangkan yang bersih dapat digunakan.

\subsection{Proliferasi tunas in vitro}

Proliferasi atau multiplikasi tunas in vitro dilakukan dengan cara menumbuhkan ujung tunas pada media MS yang mengandung Benzyl Amino Purine (BAP) $1 \mathrm{mg} / \mathrm{l}$. Kultur tunas tersebut selanjutnya diinkubasikan dalam ruangan bersuhu $25^{\circ} \mathrm{C}$ yang diberi pencahayaan dari lampu TL selama 16 jam per hari.

\subsection{Radiasi sinar gamma}

Tunas in vitro 2 kultivar lidah buaya diradiasi dengan sinar gamma dengan dosis 10-60 gy (Tabel 1) bertempat di Badan Tenaga Atom Nasional (BATAN) di Jakarta.

Semua tunas dan kalus yang telah diradiasi langsung disubkultur ke media MS segar dengan komposisi serupa yaitu mengandung $1 \mathrm{mg} / \mathrm{l} \mathrm{BAP}$ untuk tunas in vitro. Subkultur ke media segar dengan komposisi serupa dilakukan dengan interval 4 minggu sekali. Untuk menginduksi pembentukan akarnya, tunas in vitro yang sudah cukup besar disubkultur ke media MS tanpa zat pengatur tumbuh

Tabel 1: Kombinasi perlakuan dosis dan lama radiasi sinar gamma terhadap tunas in vitro dan kalus 2 kultivar lidah buaya

\begin{tabular}{|c|c|c|}
\hline No & Dosis (gy) & Waktu (detik) \\
\hline 1 & 10 & 26 \\
\hline 2 & 20 & 52 \\
\hline 3 & 30 & 78 \\
\hline 4 & 40 & 105 \\
\hline 5 & 50 & 131 \\
\hline 6 & 60 & 157 \\
\hline
\end{tabular}

\subsection{Pengamatan terhadap varian yang muncul}

Tunas in vitro lidah buaya hasil radiasi setelah disubkultur 2-3 kali, diamati keadaan morfologi dan pertumbuhannya secara visual. Pengamatan dilakukan terhadap bentuk dan wara daun serta pertumbuhan tunasnya.

\section{HASIL DAN PEMBAHASAN}

\subsection{Proliferasi tunas in vitro}

Perbanyakan in vitro Aloe vera sudah berhasil dikembangkan ${ }^{8,9}, 10$ ). Pada media MS yang mengandung $1 \mathrm{mg} / \mathrm{l}$ BAP dan $20 \mathrm{mg} / \mathrm{l}$ Adenin, jumlah rataan tunas bisa sampai 39,2 dalam waktu 10 minggu. Demikian pula dengan perbanyakan in vitro $A$. vera var. Chinensis, tunas in vitro varietas ini juga dapat diperbanyak pada media MS yang diberi $1 \mathrm{mg} / \mathrm{l}$ BAP. Dalam waktu 1 bulan penggandaan tunas bisa mencapai 15 kali lipat. Pengakaran tunas berhasil baik dalam media MS tanpa hormon. BAP memang merupakan hormon sitokinin sintetik yang banyak berhasil dalam menginduksi pengandaan tunas pada banyak tanaman ${ }^{11)}$. 
Hashelmabadi dan Kaviani (2008), juga telah berhasil memperbanyak Aloe vera pada media MS yang diberi $0,5 \mathrm{mg} / \mathrm{l}$ BAP dan $0,5 \mathrm{mg} / \mathrm{INAA}^{9}$. Demikian pula Kalimuthu et al (2010), yang menggunakan media MS yang diberi $1,5 \mathrm{mg} / \mathrm{l} \mathrm{BAP}$ dan $50 \mathrm{mg} / \mathrm{l} \mathrm{AS}{ }^{10}$ ).

Hasil penelitian pada A.vera var. Chinensis tersebut sesuai dengan penelitian yang dilakukan oleh Liao et al (2004) pada varietas yang sama ${ }^{12)}$. Tunas yang ditumbuhkan pada media MS setengah padat yang mengandung $2 \mathrm{mg} \mathrm{BA}, 0,3 \mathrm{mg}$ NAA, 0,6 g PVP dan $30 \mathrm{~g} / \mathrm{l}$ sukrosa, akan mengganda menjadi 15 kali dalam waktu 4 minggu. Pengakaran spontan terjadi pada media MS $1 / 2$ konsentrasi, namun presentase pembentukan akar meningkat dengan pemberian 0,2 mg/l NAA. Aklimatisasi planlet dari kondisi in vitro di laboratorium ke kondisi ex vitro di kamar kaca, tidak mengalami hambatan.

Penggandaan tunas $A$. vera lebih tinggi dibandingkan dengan A.vera var. Chinensis. Hal tersebut sesuai dengan kemampuan perbanyakan di alam, lidah buaya kecil anakannya lebih banyak daripada lidah buaya besar.
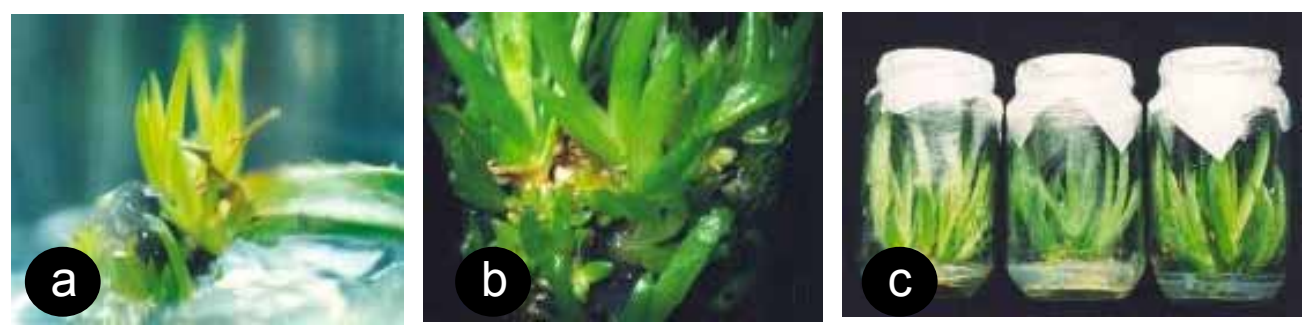

Gambar 2: a.Tunas majemuk yang muncul dari pangkal daun Aloe vera; $b$.Tunas in vitro A. vera 10 minggu setelah kultur; c. Planlet A. vera dalam media pengakaran (MS tanpa ZPT)

\subsection{Radiasi sinar gamma}

Pengamatan terhadap tunas in vitro lidah buaya, baik $A$. vera maupun $A$. vera var. Chinensis yang telah diradiasi dengan sinar gamma pada dosis 10-60 gy, dan telah disubkultur ke media MS yang mengandung $1 \mathrm{mg} / \mathrm{BAP}$, dilakukan dengan interval 2 minggu sekali. Pengamatan yang dilakukan 2 minggu setelah tunas tersebut diradiasi dengan sinar gamma menunjukkan bahwa pada dosis 10-40 gy tunas tumbuh dan berwarna hijau. Namun, pada dosis 50 gy tunas menjadi kuning kecoklatan dan pada dosis 60 gy tunas berubah menjadi kehitaman dan akhirnya mati (Tabel 2, Gambar 3, 4).

Tabel 2 : Pengaruh dosis iradiasi sinar gamma terhadap daya penggandaan dan kualitas tunas in vitro lidah buaya

\begin{tabular}{|c|c|c|c|c|}
\hline \multirow{2}{*}{ No } & \multirow{2}{*}{$\begin{array}{l}\text { Dosis } \\
\text { radiasi } \\
\text { (gy) }\end{array}$} & \multicolumn{2}{|c|}{$\begin{array}{c}\text { Daya penggandaan } \\
\text { tunas }\end{array}$} & \multirow{2}{*}{$\begin{array}{l}\text { Warna } \\
\text { tunas }\end{array}$} \\
\hline & & $\begin{array}{l}\text { A.vera var } \\
\text { Chinensis }\end{array}$ & A.vera & \\
\hline 1 & 10 & 3,9 & 7,4 & hijau \\
\hline 2 & 20 & 4,1 & 2,6 & hijau \\
\hline 3 & 30 & 0,4 & - & hijau \\
\hline 4 & 40 & 1,6 & - & hijau \\
\hline 5 & 50 & - & - & coklat \\
\hline 6 & 60 & - & - & hitam \\
\hline
\end{tabular}
setelah radiasi sinar gamma menunjukkan bahwa pada umumnya penyinaran menurunkan daya proliferasi tunas, makin rendah dosis penyinaran proliferasinya makin tinggi (Tabel 2). A. vera var. Chinensis nampaknya lebih tahan terhadap radiasi dibandingkan dengan $A$. vera, namun daya 

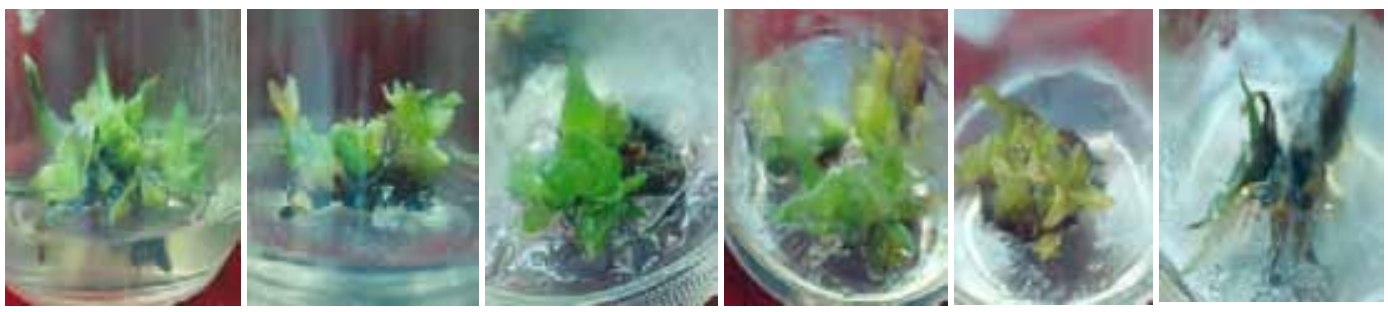

Gambar 3 : Tunas Aloe vera var Chinensis 12 minggu setelah radiasi sinar gamma dengan dosis: a.10 gy, b. 20 gy, c. 30 gy; d. 40 gy, e. 50 gy dan f. 60 gy
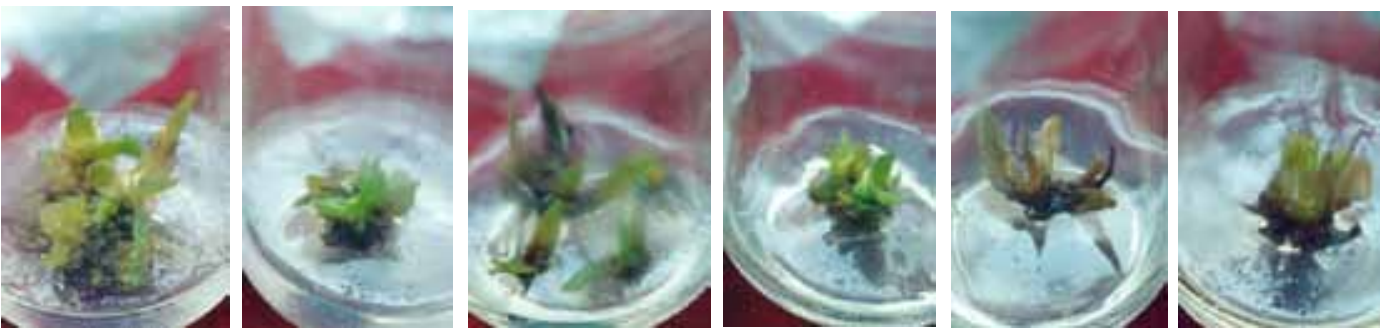

Gambar 4 : Tunas Aloe vera 12 minggu setelah radiasi sinar gamma dengan dosis : a. 10 gy; b. 20 gy; c.30 gy; d. 40 gy; e. 50 gy dan f. 60 gy

multiplikasinya lebih rendah. Tunas A. vera var. Chinensis masih tumbuh sampai dosis 40 gy, namun $A$. vera hanya tahan sampai dosis 20 gy. Pada dosis $50-60$ gy semua tunas menjadi kehitaman dan akhirnya mati (Tabel 2, Gambar 3,4). A. vera hasil radiasi 10 gy menghasilkan tunas yang berwarna hijau $(70,9 \%)$, putih kekuningan $(17,8 \%)$ dan hitam (11,3\%), namun pada $A$. vera var. Chinensis tidak ditemukan tunas yang abnormal (berwarna putih).
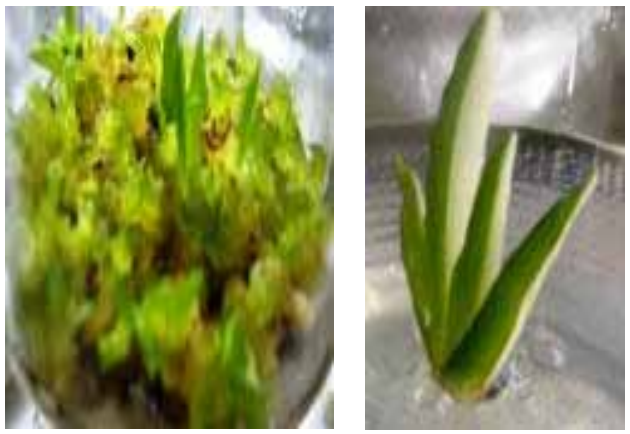

Pada dosis rendah (10gy) tampak bahwa penggandaan tunas menjadi sangat tinggi, sehingga jumlah tunas/bakal tunasnya sulit dihitung (Gambar 5 a, Tabel 3). Pada dosis $20 \mathrm{gy}$, ditemukan tunas yang daunnya setengah putih setengah hijau pada A. vera (Gambar 5 b) dan satu per tiga hijau pada A.vera var Chinensis (Gambar $5 \mathrm{c}$ ). Pada dosis yang lebih tinggi (40 gy) tampak tunas A.vera var Chinensis menjadi kaku (Gambar $5 \mathrm{~d})$.
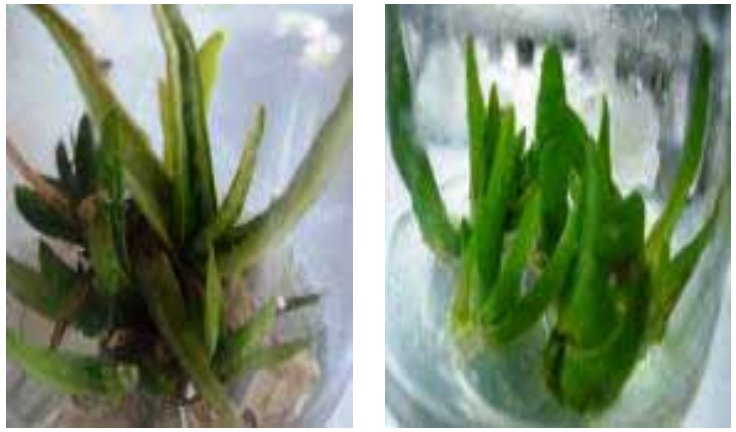

Gambar 5 : a. Tunas in vitro A. vera hasil radiasi $10 \mathrm{gy}$; b. Tunas $A$. vera berdaun setengah putih hasil radiasi 20 gy; c. A.vera var. Chinensis hasil radiasi 20 gy; d. A.vera var Chinensis hasil radiasi 40 gy 
Tabel 3: Proliferasi tunas in vitro A.vera var. Chinensis dan A.vera 9 bulan setelah iradiasi sinar gamma

\begin{tabular}{|c|c|c|c|c|c|}
\hline \multirow{2}{*}{$\begin{array}{c}\text { Dosis } \\
\text { radia }\end{array}$} & $\begin{array}{c}\text { Jum } \\
\text { lah } \\
\text { tunas } \\
\text { si } \\
\text { (gy) }\end{array}$ & $\begin{array}{c}\text { sebe } \\
\text { lum } \\
\text { radia } \\
\text { si }\end{array}$ & \multicolumn{2}{|c|}{$\begin{array}{c}\text { A.vera var. } \\
\text { Chinensis }\end{array}$} & \multicolumn{2}{|c|}{ A.vera } \\
\cline { 3 - 6 } & $\begin{array}{c}\text { Hijau/ } \\
\text { kuning }\end{array}$ & hitam & $\begin{array}{c}\text { Hijau/ } \\
\text { kuning }\end{array}$ & hitam \\
\hline 10 & 28 & 258 & 26 & 1166 & - \\
\hline 20 & 37 & 102 & 2 & 282 & - \\
\hline 30 & 36 & 25 & - & - & 7 \\
\hline 40 & 28 & 77 & - & - & 3 \\
\hline 50 & 25 & - & - & - & 5 \\
\hline 60 & 26 & - & - & - & 5 \\
\hline
\end{tabular}

Pada umur 9 bulan setelah radiasi sinar gamma, tampak bahwa pada dosis 10 gy tunas in vitro A.vera menunjukkan daya multiplikasi yang sangat tinggi, dari 28 tunas menjadi 1166 tunas. Demikian pula pada A.vera var. Chinensis, dari 28 tunas menjadi 258 tunas yang berwarna kuning atau hijau dan 26 tunas berwarna hitam. Semua tunas yang berwarna hitam akhirnya mati. Pada dosis 20 gray, multiplikasi tunas in vitro juga masih tinggi, dari 37 tunas menjadi 102 tunas pada A.vera var. Chinensis dan menjadi 282 tunas pada A.vera. Namun, pada dosis radiasi $30-40$ gy banyak tunas yang mati walaupun masih ada yang hidup, sedangkan pada dosis 50 dan 60 gy semua tunas mati (Tabel 3, Gambar 6).

Uraian di atas menunjukkan bahwa dosis radiasi sinar gamma yang rendah (10 gy), dapat menstimulasi penggandaan dan pertumbuhan kultur in vitro lidah buaya. Selain itu, sinar gamma juga dapat mempengaruhi fenotipe atau morfologi tunas, daun serta kadar klorofil daun.

Dilaporkan oleh Mohan Jain and Maluszynski (2004) ${ }^{13)}$ bahwa kondisi serupa itu, yaitu meningkatnya jumlah tunas in vitro pada dosis penyinaran 10 gy, juga dijumpai pada kultur in vitro beberapa

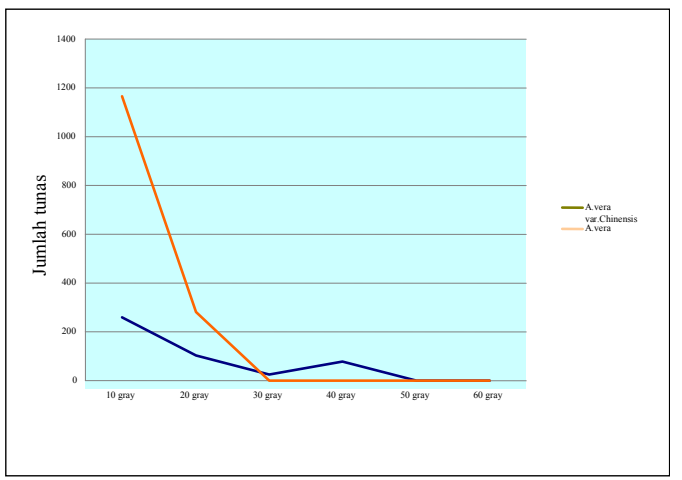

Gambar 6 : Pengaruh radiasi sinar gamma terhadap jumlah tunas lidah buaya

tanaman seperti potongan hipokotil pigeon pea, tunas anggrek Demikian pula pada Curcuma alismatifolia ${ }^{14)}$, radiasi sinar gamma mempengaruhi pertumbuhan meliputi tinggi tanaman, jumlah tunas dan daun serta perubahan morfologi, pembungaan dan klorofil. Pada anggrek Dendrobium kahaloa Beauty, radiasi sinar gamma dengan dosis 32,5 gy, merubah tinggi tanaman, panjang tangkai perbungaan, ukuran bunga dan lain-lain ${ }^{15)}$. Radiasi sinar gamma juga dilaporkan dapat memelihara potensi embriogenesis somatik tanaman kurma selama beberapa tahun tanpa kehilangan potensi regenerasinya ${ }^{13)}$.

Keunggulan lain dari mutagenesis in vitro adalah mutagen dapat diberikan terhadap sejumlah besar bakal tunas/ embriosomatik, penggandaan material tanaman mutan dapat dilakukan dengan cepat, seleksi mutan dapat dilakukan dalam kondisi in vitro serta tidak membutuhkan ruangan yang besar ${ }^{13)}$.

\section{KESIMPULAN DAN SARAN}

\subsection{Kesimpulan :}

1. Mutagenesis yang diinduksi pada kultur in vitro lidah buaya dengan dosis radiasi $10-60$ gy menunjukkan bahwa tunas $A$.vera var .Chinen- sis. tetap hidup sampai dosis 40 gy, tunas 
A.vera hanya tahan sampai dosis 20 gy, sedangkan pada dosis $50-60$ gy semua tunas mati.

2. Dosis radiasi sinar gamma yang rendah yaitu $10 \mathrm{gy}$, ternyata meningkatkan daya multiplikasi tunas in vitro A.vera maupun A.vera var.Chinensis.

3. Dosis radiasi yang lebih tinggi yaitu 20gy, menghasilkan perubahan kadar klorofil dan dosis 40 gy menimbulkan kekakuan daun pada A.vera var. Chinensis.

\subsection{Saran}

Penelitian ini perlu dilanjutkan dengan pengujian kestabilan genetik mutan menggunakan marka molekuler seperti Random Amplified Polymorphic DNA(RAPD) ataupun Inter Simple Sequence Repeats (ISSR), untuk mengkonfirmasi apakah perubahan morfologi tersebut bersifat genetik.

\section{DAFTAR PUSTAKA}

1. Santosa, E. and L.K.Darusman. 2002. Kajian potensi dan pengembagnan produk lidah buaya (Aloe vera). Makalah dalam Pertemuan Nasional Pengembangan |Lidah Buaya, Pontianak 21-22 Juni 2002

2. Panggabean, F.I. 2002. Lidah buaya sembuhkan bermacam penyakit berat. Harian Kompas, Juli.

3. Anonim. 2005. Sehat dengan lidah buaya. Suara Karya, 28 Februari 2005

4. Sumarno. 2002. Program Pengembangan lidah buaya di Indonesia. Makalah dalam Pertemuan Nasional Pengembangan Lidah Buaya, Pontianak 21-22 Juni.

5. Marino, G., S.Begheli, A.D.Rombola and L. Cabrini. 2000. In vitro performance at high culture $\mathrm{pH}$ and in vitro response to Fe-deficiency of leaf-derived quince BA 29 (Cydonia oblonga) somaclones regenerated at variable $\mathrm{pH}$. Hort.Sci. Biotechnol.75 : 33-44

6. Predieri, S. and G. Edoardo. 2004. In vitro techniques and physical mutagens for the improvement of fruit crops. In : In Vitro Application in Crop Improvement, A. Mujib, Myong-Je Cho, S. Predieri, and S. Banerjee (Eds), Oxford \& IBH Publishing Co. Pvt. Ltd. New Delhi. p.19-34.

7. Murashige T and F Skoog. 1962. A revised medium for rapid growth and bio-assays with tobacco tissue cultures. Physiol. Plant. 15: 473-497.

8. Sari L dan M. Imelda, 2004. Pengaruh Benzyl Amino Purine (BAP) dan Adenin Sulfat (AS) terhadap multiplikasi tunas dan jumlah daun in vitro lidah buaya (Aloe vera (L) Burn.f). Jurnal Stigma, an Agricultural Science Journal XII(4): 413-416.

9. Hashelmabadi, D. and B. Kaviani. 2008. Afr.J.Biotechnol. 7 (12) : 1899-1902.

10. Kalimuthu, K., S. Vijayakumar, R.Senthilkumar and M.Surehkumar. 2010. Micropropagation of Aloe vera Linn.- a medicinal plant. Int.J. of Biotechnol. and Biochem. 6 (3) : 405410.

11. George, E. F. and P. D. Sherrington. 1984. Plant propagation by tissue culture. Exegetics Limited, England, $690 p$.

12. Liao, Zhihua; Min Chen, Feng Tan, Xiaofen Sun and Kexuan Tang, 2004. Micropropagation of endangered Chinese aloe. Plant Cell Tiss.Organ Cult. 76(1): 83-86. 
13. Mohan Jain, S. and M. Maluszynski. 2004. Induced Mutations and Biotechnology in Improving Crops. In : In Vitro Application in Crop Improvement edited by A.Mujib, Myeong-Je Cho, S. Predieri and S. Banerjee. Oxford \& IBHPublishing Co.Pvt.Ltd, New Delhi, p. $169-202$

14. Abdullah, T.L., J. Endan and B.M.Nazir.2009. Changes in flower development, chlorophyll mutation and alteration in plant morphology of Curcuma alismatifolia by gamma irradiation. Am.J.Applied Sci.6(7): 1436-1439

15. Rahayu , S. (1985). The effect of gamma irradiation on Dendrobium kohaloa Beauty. Proceedings of Seminar on the Application of Nuclear Techniques in Agriculture , 9-10 July 1985 , Jakarta , Indonesia. p175-183. Published by PAIR BATAN (in Indonesian). 